\title{
Arsitektur Rumah Balla Lompoa Galesong Suku Makassar sebagai Sumber Materi Geografi Budaya
}

\author{
Syamsuriadi $^{1}$, I Komang Astina ${ }^{1}$, Singgih Susilo ${ }^{1}$ \\ ${ }^{1}$ Pendidikan Geografi-Universitas Negeri Malang
}

\begin{tabular}{l} 
INFO ARTIKEL \\
\hline Riwayat Artikel: \\
Diterima: 09-05-2019 \\
Disetujui: 10-12-2019 \\
\hline
\end{tabular}

\section{Kata kunci:}

architecture;

Makassar tribe;

cultural geography;

arsitektur;

suku Makassar;

geografi budaya

\author{
Alamat Koresponden: \\ Syamsuriadi \\ Pendidikan Geografi \\ Universitas Negeri Malang \\ Jalan Semarang 5 Malang \\ E-mail: syamsuriadiunmum@gmail.com
}

\begin{abstract}
ABSTRAK
Abstract: The purpose of this study was to describe the meaning of the balla lompoa symbol Galesong in the Makassar tribe while still looking at the geographic context behind the shape of the balla lompoa house. This type of research is qualitative descriptive using an ethnographic approach with a perspective of symbolic interaction. The results of this study indicate that the symbols on balla lompoa have a meaning that is guided by the philosophy of the Makassar tribe, namely sulapa appaka (square). The form of balla lompoa Galesong Makassar tribe is also motivated by the location of the Galesong region which is the coastal area of the Makassar Strait. The meaning and value of the balla lompoa is very relevant to be used as a source of material in the Culture Geography Course, Department of Geography, Faculty of Mathematics and Natural Sciences, Makassar State University.

Abstrak: Tujuan dari penelitian ini untuk mendeskripsikan makna simbol balla lompoa di Galesong pada suku Makassar dengan tetap melihat konteks geografi yang melatarbelakangi bentuk rumah balla lompoa itu. Jenis penelitian ini deskriptif kualitatif menggunakan pendekatan etnografi dengan perspektif interaksi simbolik. Hasil penelitian ini menunjukkan bahwa simbol pada balla lompoa memiliki makna yang berpedoman pada falsafah suku Makassar yaitu sulapa appaka (persegi empat). Bentuk balla lompoa Galesong Suku Makassar juga dilatarbelakangi oleh letak wilayah Galesong yang merupakan wilayah pesisir pantai selat Makassar. Makna dan nilai balla lompoa tersebut sangat relevan untuk dijadikan sumber materi pada matakuliah Geografi Budaya Jurusan Geografi Fakultas MIPA Universitas Negeri Makassar.
\end{abstract}

Peradaban masa lalu dianggap oleh generasi muda merupakan sesuatu yang ketinggalan sehingga berpotensi untuk dilupakan. Pada kehidupan akan terjadi pembaruan dengan berdampak pada mengikisnya nilai budaya yang ada di bangsa kita. Perkembangan zaman membuat generasi melenial mengalami begitu banyak persoalan (Syarif, Hasriyanti, Fatchan, Astina, \& Sumarmi, 2016). Tantangan dalam melawan kepentingan dan sikap individual antara kebersamaan bisa memicu masalah sosial (Hendra, Budijanto, \& Ruja, 2018). Salah satu peradaban kita sabagai bangsa yang beragam adalah melihat bentuk dari rumah adatnya yang juga beragam seperti yang ada di Sulawesi Selatan lebih tepatnya di kecamatan Galesong yang disebut juga balla lompoa (rumah kebesaran) yang ada di Kabupaten Takalar. Jika dipahami, peradaban masa lalu merupakan gambaran tingkat intelektual leluhur yang hidup pada saat itu. Oleh karena itu, menggali dan melestarikan peradaban arsitektur rumah yaitu balla lompoa kita dan generasi milenial akan mengetahui cara berkembang kecerdasan manusia dari tiap masanya. Kecerdasan beradaptasi leluhur masa lalu juga akan memberikan gambaran perkembangan manusianya. Kekayaan tradisional pada masyarakat di Sulawesi Selatan tercermin dari beragamnya entitas budaya dan khazanah nilai yang diinterpretasikan sebagai keseimbangan hidup antara manusia, ketuhanan dan alam hingga khazanah arsitektur yang merepresentasikan makna dan nilai luhur.

Kepercayaan para leluhur terhadap bentuk bangunan dan posisi bangunan rumah akan memberikan variasi bernuansa tersendiri. Kepercayaan tersebut bagi masyarakat Suku Makassar saat ini dihadapkan pada tantangan untuk melestarikannya yang secara perlahan terus menghadapi proses modernisasi. Tidak dapat dipungkiri bahwa dari beberapa peninggalan arsitektur tradisional salah satu diantaranya yakni bangunan rumah adat sebagian sudah ada yang mengalami pelapukan bahkan sampai punah termakan usia (Ansaar, 2015). Balla lompoa berbentuk rumah panggung sarat akan simbol yang mengandung makna dan nilai sosial. Banyak bangunan yang bersejarah dan mempunyai makna simbolik dan arsitektur yang unik dan menarik (Rahmawati \& Nurcahyo, 2018). Simbol budaya tersebut hanya saja belum memublikasikan secara menyuluh ke masyarakat. 
Berdasarkan hasil observasi awal pada masyarakat umum, pengetahuan dan pemahaman masyarakat tentang representasi makna rumah panggung hanya diketahui oleh beberapa orang. Pemahaman masyarakat tentang representasi rumah panggung hanya dipengaruhi oleh kondisi sosial ekonomi, padahal di dalam struktur bentuk rumah adat panggung itu terdapat representasi alam dan manusia. Hal ini tercermin dari masih adanya masyarakat yang belum memahami akan arti simbol pada arsitektur balla lompoa.

Arsitektur tradisional lahir dari kebutuhan manusia untuk melindungi diri dari cuaca pada musim tertentu. Bentuknya bervariasi mengikuti bahan bangunan yang tersedia tidak terkecuali yang ada di kabupaten Takalar. Sejarawan dan antropolog serta para budayawan sudah mengenal kepulauan Indonesia sebagai tanah dan orang-orang dengan tradisi bangunan lama untuk iklim tropis basah yang terbuat dari konstruksi bambu dan kayu (Wiryomartono Bagoes, 2013). Oleh karena itu, arsitektur tradisional yang dimiliki oleh suku Makassar sangat terkait dengan kondisi dan potensi sumber daya alam sekitarnya serta perlu dilestarikan. Beberapa masyarakat membuat rumah dengan bentuk semi permanen atau panggung yang tidak jauh berbeda dengan struktur rumah balla lompoa. Masyarakat yang masih memiliki rumah dalam bentuk semi permanen ini ternyata tidak semuanya memahami secara persis akan makna dari arsitektur tersebut. Sebagai produk dari proses berpikir yang inovatif, kreatif, dan produktif secara bersama-sama membentuk sistem hidup yang berkesinambungan dengan masyarakat yang dibangun oleh adat, norma ataupun kebiasaan berupa tradisi yang telah membudaya. Balla lompoa yakni rumah adat di Galesong ini masih bertahan salah satunya karena bagi masyarakat, rumah tersebut berarti rumah besar dan merupakan suatu simbol kebudayaan yang beridentitas. Struktur bangunan terdahulu tersebut memberi pandangan dan sekaligus sebagai identitas kesukuan bagi masyarakat pendorong kebudayaan (Johansen, 2014).

Indonesia sendiri memiliki berbagai provinsi tiap-tiap daerah mencetuskan rumah adatnya sendiri. Pulau Sumatera yakni rumah adat Krong Bede, Balon, Gandag, Sulaso, Bubung, Panggung Kajang, Limas, Rakit Limas, Rakyat, dan nowou sesat. Pulau Jawa yakni rumah adat badui, Sunda, Joglo jawa tengah, Bangsal Kencono, Joglo Jawa timur, Tanean lanjhang, dan Kebaya, pulau Sulawesi yakni, rumah adat Pewaris, Tambi, Buton, Tongkonan, Dulokopa, dan Mandar. Pulau Kalimantan yakni rumah adat Panjang, Betang, Lamin, Bubungan Tinggi, dan Baloy. Pulau Bali yakni rumah adat Gapuran Candi Bentar. Pulau Nusa Tenggara yakni rumah adat Musalaki dan Dalam Lokal. Pulau Maluku yakni rumah adat Baiko dan Sasadu. Pulau Papua yakni rumah adat Honai, Mod Saki Aksa, dan Lgkojei. Bahkan terdapat wilayah provinsi yang mempunyai rumah adat hampir disetiap wilayah kabupaten. Salah satunya rumah adat Tongkonan, Mamasa, Saoraja Tenri Bali, Labakkang, Buki, Bola Soba, Sao Mario, Balla Lompoa, Letta, dan Langkanae. Pemanfaatan kebudayaan yang ada pada lingkungan sekitar peserta didik sebagai materi ajar akan meluaskan kajian kontekstual yang sudah ada pada pembelajaran. Perlunya mengetahui proses dari budaya lokal yang ada di sekitar lingkungan mahasiswa untuk menghadapi globalisasi (Syamsunardi, 2017). Bahan ajar Geografi yang ideal yakni bersumber pada lingkungan sekitar peserta didik. Pembelajaran seharusnya mengaitkan antara dunia nyata mahasiswa dengan materi yang akan diajarkan sehingga dalam pembelajaran akan diperoleh pengetahuan yang bermakna dan bermanfaat (Syarif, 2017).

Matakuliah Geografi Budaya sangat relevan dijadikan sebagai salah satu cara mengomunikasikan kepada mahasiswa mengenai makna simbolik pada konstruksi balla lompoa pada proses pembelajaran. Objek geografi tidak hanya landskap (bentang alam) tetapi memisahkan pengertian landskap budaya dan landskap alam. Geografi budaya merupakan sub bidang ilmu geografi manusia yang mempelajari studi tentang produk budaya, norma, dan variasi mereka menemukan dan hubungan dengan ruang dan tempat (Suharyono, 2013). Berdasarkan hal tersebut arti budaya pada konstruksi rumah balla lompoa sangat berpotensi untuk diintegrasikan dalam pembelajaran Geografi Budaya pada topik budaya lokal. Penelitian ini bermaksud menggali informasi serta mengungkap makna arsitektur balla lompoa di Kabupaten Takalar yang dapat dijadikan sumber pembelajaran Geografi Budaya. Konteks Geografi yang melatarbelakangi arsitektur balla lompoa juga akan dipertimbankan dalam memahami pemaknaannya. Penelitian ini berbeda dengan yang lain karena hasil dari penelitian ini dimanfaatkan sebagai materi pada topik budaya lokal matakuliah Geografi Budaya.

\section{METODE}

Pendekatan etnografi digunakan dalam penelitian ini yang juga merupakan salah satu pendekatan pada penelitian kualitatif dengan memakai perspektif Interaksi simbolik. Pendekatan etnografi merupakan suatu pendekatan yang digunakan dalam mengkaji arsitektur budaya balla lompoa yang ada komunitas masyarakat serta mengungkap makna yang ada pada kebudayaan. Lokasi penelitian berada di desa Galesong Baru Kecamatan Galesong Kabupaten Takalar, Sulawesi Selatan. Pengumpulan data yang akan dipakai oleh peneliti dalam penelitian ini adalah observasi partisipan, melakukan pengamatan langsung terhadap apa yang dibicarakan diantara subjek penelitian seperti wawancara mendalam dan dokumentasi. Analisis yang digunakan peneliti adalah analisis interaktif (Miles \& Huberman, 1984).

Proses pengecekan keabsahan data dengan audit trail untuk memverifikasi keabsahan data. Audit ini dapat terjadi selama berkali-kali dan di akhir penelitian. Penelitian ini yang bertindak sebagai seorang audit adalah pembimbing peneliti. Drs. I Komang Astina, M.S.,Ph.D sebagai pembimbing I dan Dr. Singgih Susilo, M.S.,M.Si sebagai pembimbing II. Pada tahap ini sejumlah konsultasi diadakan oleh peneliti dan auditor. Selama proses konsultasi atau pemeriksaaan rancangan laporan hasil penelitian auditor memberi respons. Jika dari sisi auditor terlihat adanya perbaikan, hal itu dibicarakan untuk kemudian diperbaiki. Penulisan rancangan hasil penelitian tidak hanya dilakukan satu kali, tetapi senantiasa berkembang mengikuti dengan hasil revisi. Hasil penelitian ini kemudian dibuat dalam bentuk laporan etnogafi yang digunakan sebagai sumber materi 
matakuliah Geografi Budaya. Materi yang dimaksud adalah memahami budaya lokal yang akan digunakan pada lingkup Jurusan Pendidikan Geografi Fakultas MIPA Universitas Negeri Makassar.

\section{HASIL}

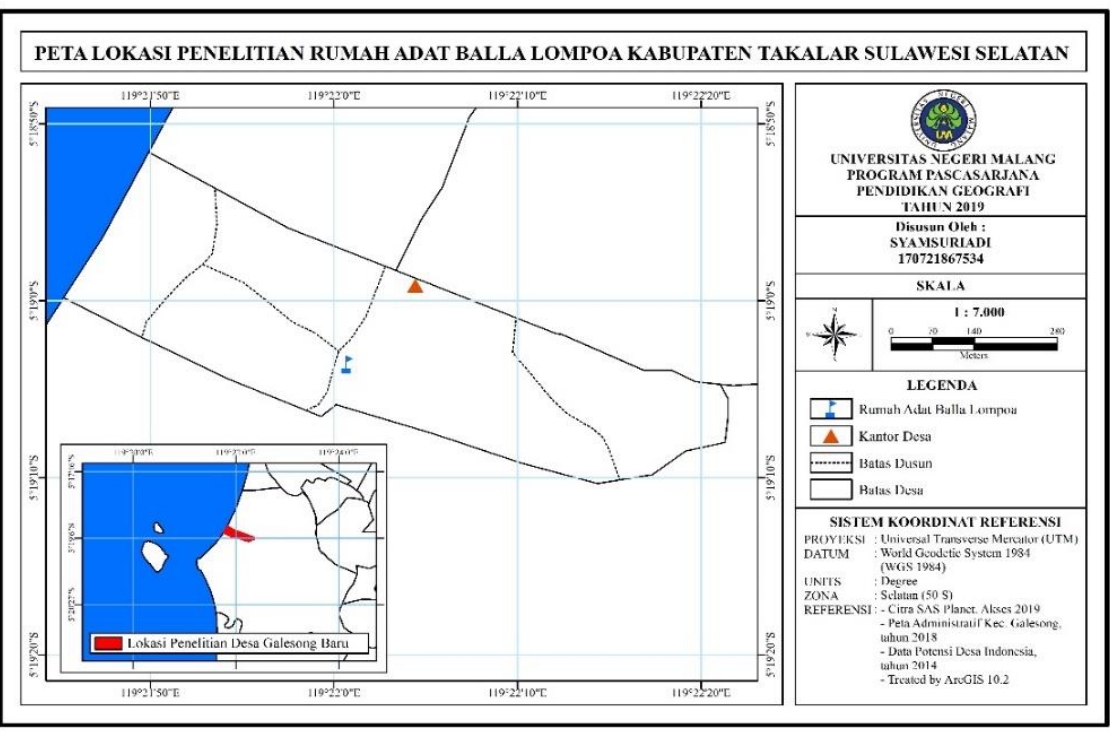

Gambar 1. Peta Lokasi Penelitian Desa Galesong Baru Kecamatan Galesong

Lokasi Kecamatan yang ada di Galesong semuanya ada di wilayah pesisir. Hal ini membuat masyarakat yang bertempat tinggal di Galesong lebih memahami kondisi alam agar mampu beradaptasi dengan baik, salah satunya dalam membuat rumah atau yang dulunya disebut istana kebesaran bagi karaeng (raja). Adaptasi masyarakat Galesong menunjukkan bentuk pengetahuannya mengenai alam. Masyarakat mampu memberikan respons atas apa yang diberikan oleh alam. Hal ini berkaitan dengan paham posibilisme yakni alam tidak selamanya mampu mengikuti ataupun menanggapi setiap kehidupan dan aktivitas manusia, tetapi alam memberikan berbagai opsi untuk dipilih lalu manusia merespon setiap alternatif pilihan yang disediakan oleh alam. Alam hanyalah sebagai faktor pengontrol aktivitas manusia bukan merupakan faktor penentu, namun alam memberikan banyak peluang dan pilihan yang dapat manusia tentukan unsur-unsur kebudayannya dimana ahli geografi terkadang menyebut pendekatan ini dengan istilah lain, yaitu pendekatan fisis posibilisme.

\section{Tata Ruang Balla Lompoa}

Berdasarkan pandangan hidup dan budaya lokal (culture) orang Makassar, maka arah rumah sebaiknya menghadap ke salah satu arah mata angina utara, timur, selatan, atau barat. Berdasarkan hasil yang ditemukan dilapangan bahwa rumah yang paling baik dan bagus adalah yang menghadap atau mengarah ke kiblat ataupun mengikuti arah mata angin dengan anggapannya akan lebih aman, dan menghindari kemungkinan akan roboh oleh angin karena rumah tidak menyilang arah angin. Arah orientasi layout balla lompoa adalah utara - selatan dengan makna bahwa karaeng (raja) merupakan seseorang yang memiliki keyakinan agama Islam sehingga berpatokan pada pedoman ajaran Islam, menghadap utara - selatan dengan bagian depan rumah menghadap ke selatan, dan bagian belakang rumah menghadap ke utara. Berdasarkan ajaran Islam bahwa rumah yang baik dan bagus menghadap ke kiblat, maka rumah yang menghadap arah utara-selatan merupakan tanda bahwa pemilik rumah tersebut memiliki keyakinan Islam. Bentuk balla lompoa adalah persegi yang berpatokan pada falsafah sulapa appaka, dengan arah bangunan utara - selatan. Balla lompoa berbentuk rumah panggung dengan tiang di bawah bangunan. Benteng (tiang rumah) induk balla lompoa berjumlah tiga puluh enam buah, yaitu enam deret ke samping dan tujuh deret ke belakang. Tiang yang terdapat pada Paladang berjumlah enam belas buah. 


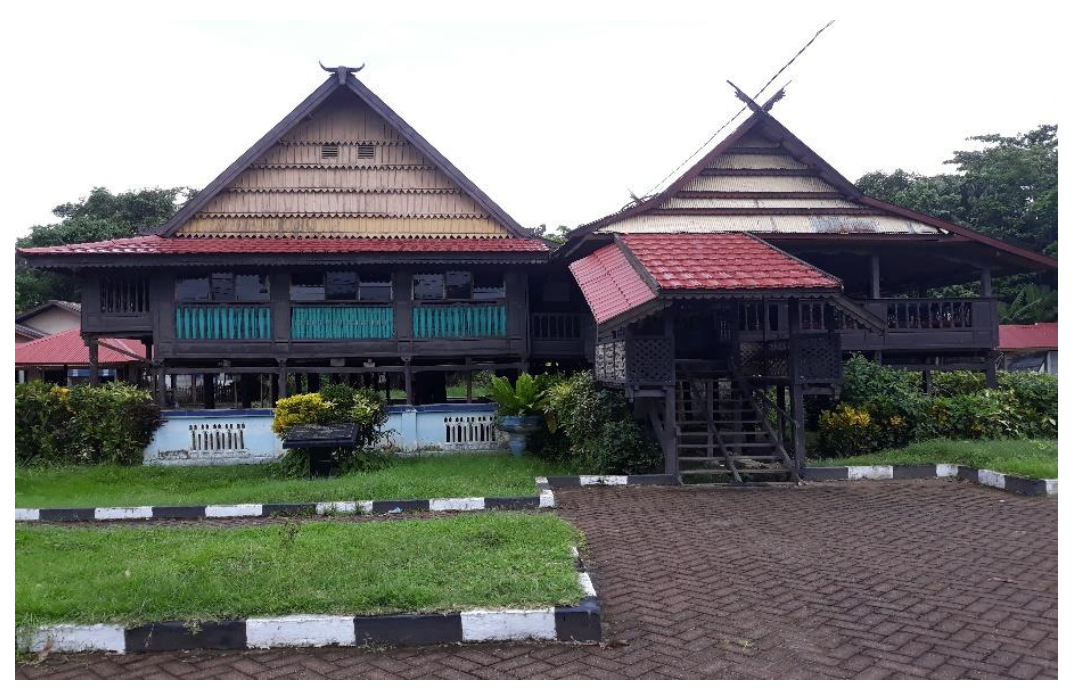

\section{Gambar 2. Rumah balla lompoa Desa Galesong Baru Kecamatan Galesong Sumber: Dokumentasi Lapangan}

\section{Tuka (Tangga)}

Pada anak tangga harus ganjil, seperti 7, 9, 11, atau 13. Jumlah genap dimaknai milik orang yang sudah meninggal. Tangga yang memakai cocorang (pegangan tangga) merupakan wujud simbolik yang memiliki makna bahwa rumah tersebut merupakan tempat raja dengan maksud bahwa untuk membedakan rumah rakyat biasa dan rumah raja. Tidak lain penggunaan coccorang sebagai pegangan tangga agar raja/pengguna tangga tersebut dapat berpegangan ketika menggunakan tangga agar lebih aman dari resiko jatuh. Bagian yang mengandung makna tersebut berubah sehingga bagi masyarakat setempat dianggap sebagai sesuatu alamiah sehingga menimbulkan mitos yang digunakan turun temurun.

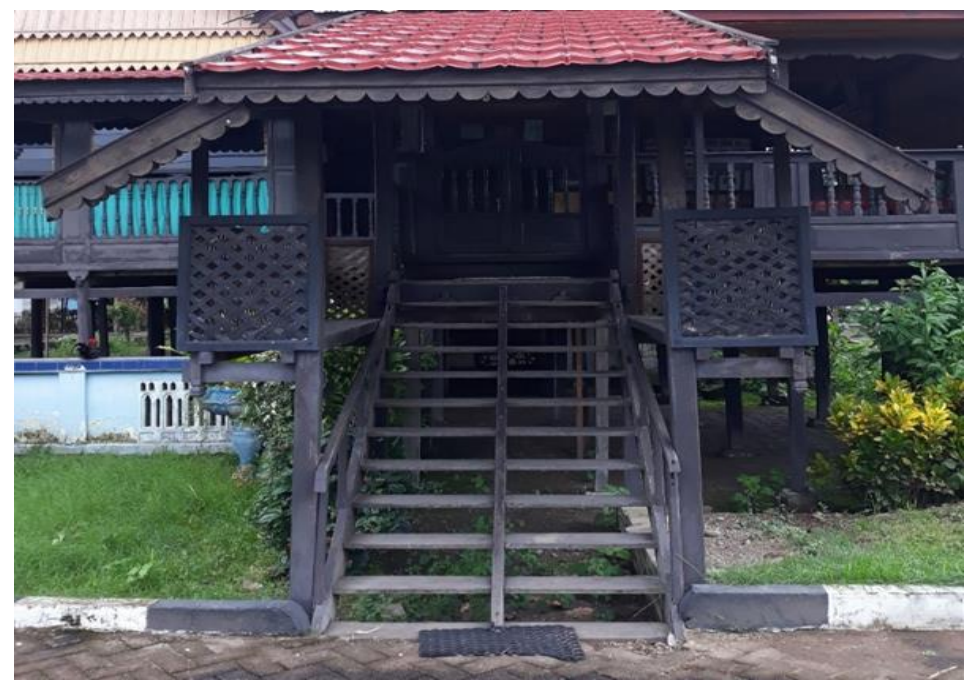

\section{Gambar 3. Tampak depan Tangga Depan dengan Cocorang (pegangang) Sumber: Dokumentasi Lapangan}

\section{Sambulayang (Bubungan)}

Jumlah sambulayang (bubungan) dan anjong (khiasan) yang digunakan pada atap rumah merupakan wujud simbolis yang membedakan status sosial seperti status sosial tinggi, menengah, dan bawah pada masyarakat. Jumlah sambulayang yang diterapkan pada balla lompoa sama dengan jumlah sambulayang yang digunakan pada rumah raja Sulawesi Selatan lainnya yaitu berjumlah lima dan terdapat anjong (khiasan) pada setiap ujung atap balla lompoa. Makna yang tersirat dalam penggunaan sambulayang dan anjong itu adalah menunjukkan bahwa bangunan ini merupakan kediaman seorang raja (orang dengan status sosial tinggi) yang menimbulkan mitos dalam kalangan masyarakat suku Makassar yang menyatakan bahwa bangunan rumah dari lapisan sosial menengah hingga terendah tidak boleh menyamai bentuk rumah lapisan sosial di atasnya. 
Sama halnya bubungan pada bagian atap induk rumah yang berjumlah lima susun, di bagian atap teras rumah juga memiliki lima susun bubungan. Lima susun bubungan pada bagian atap teras rumah balla lompoa memiliki makna bahwa negara memiliki lima dasar yaitu Pancasila. Hanya rumah balla lompoa Galesong yang memiliki lima susun bubungan dibagian paladang (teras) rumah, dimana rumah adat lainnya di Sulawesi Selatan hanya memiliki tiga susun bubungan. Semua itu didasari oleh aturan yang disepakati bersama, jika melanggar aturan itu berarti merusak tata tertib alam dan akan mendatangkan musibah.

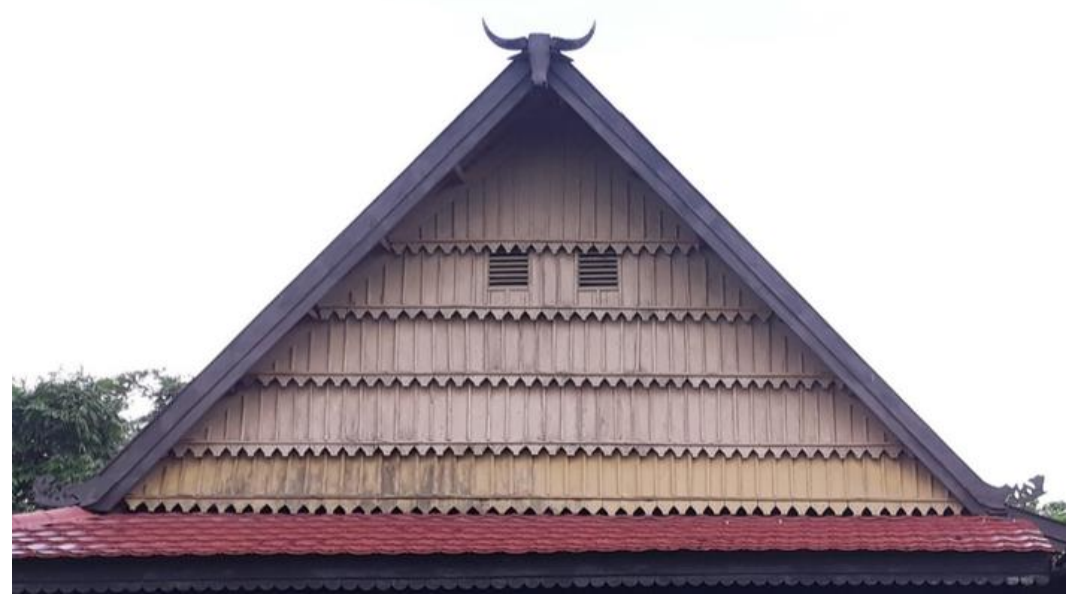

Gambar 4. Atap balla lompoa bagian induk rumah dengan sambulayang (bubungan) bersusun lima Sumber: Dokumentasi Lapangan

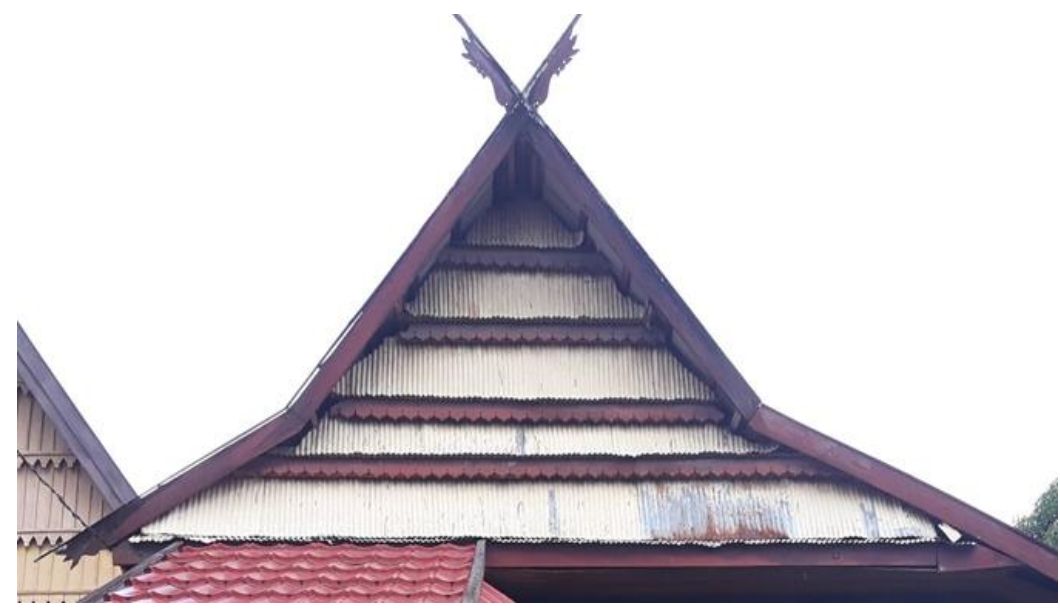

Gambar 5. Atap balla lompoa bagian teras dengan sambulayang bersusun lima. Sumber: Dokumentasi Lapangan

\section{Paladang (Teras)}

Angka yang digunakan pada ruang paladang (teras) ini merepresentasikan pada struktur alam, tidak terkecuali petak terali kayu yang berjumlah tiga petak yang mengandung makna mengacu pada struktur alam semesta. Angka tiga yang menurut kepercayaan masyarakat Galesong suku Makassar angka tiga berarti bahwa alam semesta yang jika dilihat secara garis vertikal ini terbagi atas tiga bagian, yaitu langit, bumi, dan air. Berdasarkan hal tersebut bagian teras rumah ini merupakan gambaran dari langit. Bagi masyarakat suku Makassar makna tersebut kemudian berubah menjadi mitos yang hingga saat ini dianggap sebagai sesuatu yang alamiah dalam kehidupan sosial masyarakat. 


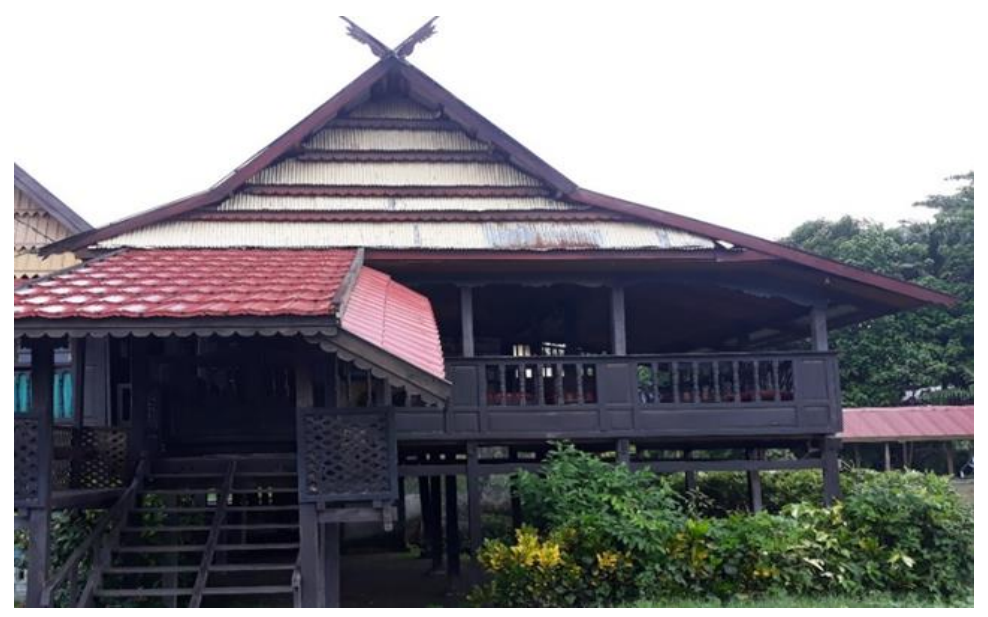

\section{Gambar 6. Bagian Depan Paladang (teras) Sumber: Dokumentasi lapangan}

\section{Rinring (Dinding)}

Makna yang tersirat adalah bentuk persegi empat ini merupakan bentuk dasar dari bentuk kayu sehingga dengan menggunakan bentuk persegi empat dapat mengefisiensikan penggunaan kayu serta proses pembuatan kayu dapat cepat diselesaikan yang hingga saat ini dianggap sebagai sesuatu yang alamiah dalam kehidupan sosial masyarakat Makassar. Berdasarkan hasil penelitian menunjukkan bahwa makna yang diterapkan pada dinding tetap berpedoman pada struktur alam, dimana secara vertikal dinding balla lompoa tergolong ke dalam alam tengah yang kalau dilihat secara garis horizontal tergolong ruang paddasserang ri tangnga (ruang keluarga). Berdasarkan hal tersebut dinding yang tergolong pada ruangan tengah merupakan gambaran dari bumi. Sementara jumlah jendela yang ada pada dinding yaitu bagian samping empat jendela yang arti simboliknya bahwa di alam semesta ini ada empat unsur, yakni air, api, angin, dan tanah. Tiga jendela bagian depan memiliki arti manusia itu ada tiga susun secara vertical, yaitu bagian atas kepala sampai dagu, bagian tengah dagu hingga pusat, dan bagian bawah yaitu pusat hingga ujung kaki.

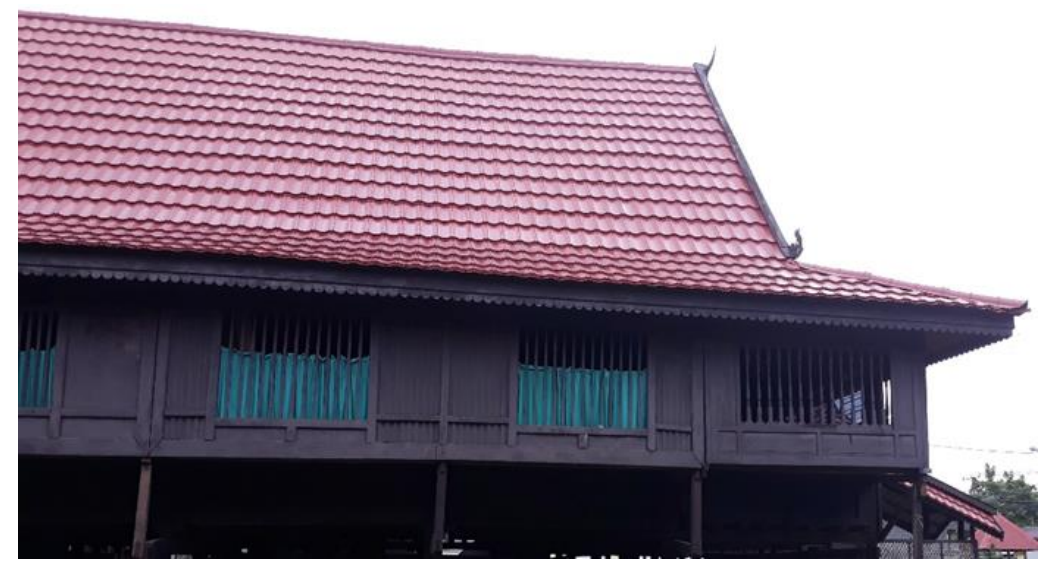

Gambar 7. Dinding tampak dari luar Sumber: Dokumentasi lapangan

\section{Pakkekbu (Pintu)}

Pintu masuk ruang Paddaserang (ruang keluarga) ini menggunakan bentuk persegi empat dan terdapat empat bentuk pada masing-masing daun pintu yang menunjukan pada angka kesempurnaan. Bentuk tersebut merupakan bentuk dasar dari kayu yang digunakan sebagai bahan utama membuat pintu, sehingga menggunakan bentuk dasar untuk mengefisienkan waktu dan biaya. Pintu masuk ke ruang keluarga itu mempunyai dua daun pintu yang mengandung makna agar semua kebahagiaan dapat terbuka dengan harapan ada aura kebaikan yang masuk ke dalam rumah balla lompoa. Penggunaan kaca pada pintu itu juga tersirat makna agar kebaikan yang masuk ke rumah akan transparan tanpa ditutupi oleh hal yang dapat merugikan penghuni rumah. 


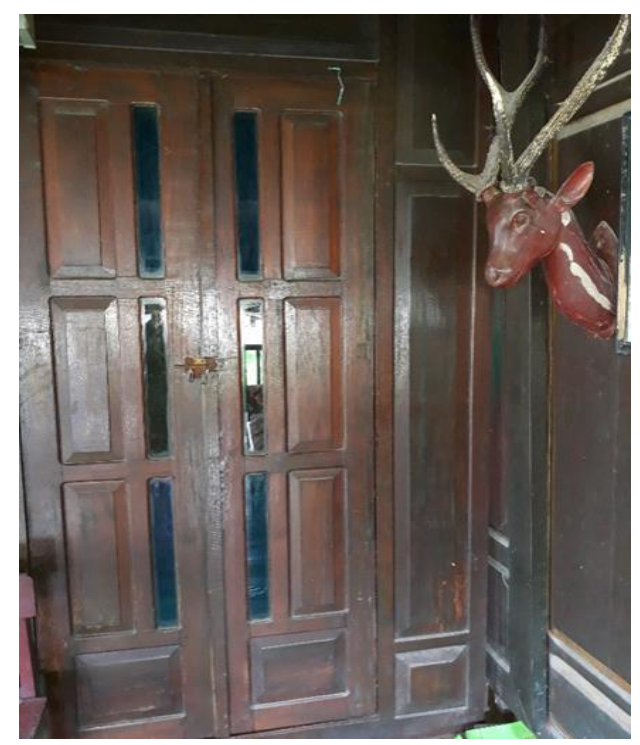

\section{Gambar 8. Pintu ke arah ruang Paddaserang Riolo (ruang depan) Sumber: Dokumentasi lapangan}

Arsitektur balla lompoa yang dapat dijumpai dalam masyarakat Suku Makassar yang secara khusus berada di Kabupaten Takalar berfungsi sebagai tempat tinggal bagi raja yang pada saat itu berjuang melawan penjajah. Fungsi balla lompoa yang lebih tampak sekarang ini lebih kepada tempat untuk melakukan suatu musyawarah yang berkaitan dengan adat setempat. Berdasarkan hasil penelitian ditemukan nilai-nilai luhur yang terkandung dalam arsitektur rumah balla lompoa, yakni nilai estetika, etika, persatuan, religius, falsafah, tanggung jawab status sosial, kejujuran, kesopanan, kepemimpinan, dan nilai kepercayaan. Nilai-nilai yang terdapat pada arsitektur balla lompoa tersebut harus dilestarikan dan diketahui oleh generasi muda dan masyarakat. Salah satu alternatifnya adalah mengintegrasikannya ke dalam proses pembelajaran khususnya pada matakuliah Geografi Budaya.

\section{PEMBAHASAN}

Asumsi teoritiknya adalah bahwa masyarakat hidup akan senantiasa membentuk interaksi simbolik yang terbentuk melalui proses interaksi dan komunikasi, baik antar individu, individu dengan kelompok, dan atau antar kelompok dengan memakai simbol yang dipahami maknanya melalui proses belajar. Tindakan yang dimunculkan oleh subjek merupakan hasil dari tahap interpretasi terhadap suatu rangsangan yang melalui tahap pemahaman. Akibat kemampuan berpikir dari masingmasing individu, maka akan dimiliki kebebasan untuk menentukan tindakannya sesuai dengan tujuan yang dikehendaki (Ritzer \& Goodman, 2012).

Bagi masyarakat Galesong yang memiliki kepercayaan bahwa tanah merupakan bagian dari bumi yang bernafas, dimana di siang hari menarik nafas dan malam mengeluarkan nafas. Pandangan hidup dan ilmu pengetahuan serta berbagai strategi kehidupan yang berwujud aktivitas yang dilakukan oleh masyarakat lokal dalam menjawab berbagai masalah dalam pemenuhan kebutuhan mereka (Ridwan, Fatchan, \& Astina, 2016). Anggapan masyarakat tersebut jika dikaitkan dengan sisi ilmiah maka hal tersebut dapat dipahami berdasarkan ilmu Geografi dari sisi respirasi tanah yakni peristiwa tanah yang bernapas dengan bantuan mikroba-mikroba kecil yang hidup di bawah tanah dan menghabiskan karbondioksida yang disimpan akar dan daun-daun mati. Karbondioksida ini dilepaskan kembali ke udara. Leluhur telah meyakinkan dalam sistem kepercayaan adat yang ketika dipahami ternyata manusia akan lebih sehat dan aman jika tinggal di rumah panggung dibandingkan tinggal di rumah yang kontak langsung dengan tanah.

Bentuk fisik topografi pada wilayah Sulawesi Selatan terbagi antara dataran tinggi dan dataran rendah sehingga membuat masyarakat beradaptasi pada lingkungan dengan membuat rumah panggung (balla kayu). Dataran tinggi juga masih bisa dijumpai rumah panggung, seperti di Kabupaten Toraja, Masamba dan sebagian wilayah pada Kabupaten Gowa, Sinjai, dan Bone, kabupaten lainnya tergolong dataran rendah. Asal mula tujuan manusia mencipta bangunan adalah menyelaraskan kondisi sekitarnya dengan pandangan hidupnya. Rumah adalah pernyataan hidup yang menyatu dengan masyarakat dan alam lingkungannya (Rachmah, 2018). Masyarakat juga menganggap rumah panggung sebagai rumah yang multifungsi seperti di bagian bawah (siring) untuk menyimpan hasil pertanian seperti jagung, di bagian tengah ata di bawah (paladang) untuk berkumpul bersama anggota keluarga, dan di bagian (paladang) untuk menyimpang padi. Hal tersebut diyakini bahwa Konstruksi rumah sangat dipengaruhi oleh kondisi alam (nature), salah satunya intensitas matahari, intensitas curah hujan, kecepatan angin, serta material bahan baku yang digunakan banyak terdapat di daerah tersebut. 
Berbeda sekali dengan adanya faktor perkembangan. Rumah hanya berfungsi sebagai tempat berteduh jika dilihat waktu masih masa berburu. Kemudian lebih kedepan ke masa cocok tanam dan dengan hidup yang mulai tetap hampir semua kegiatan kehidupan diawali atau dilaksanakan di rumah begitupun ketika bersosialisasi dimulai dalam rumah. Keberlangsungan hidup masyarakat saat ini tentu sulit untuk dapat dipisahkan dari dunia kebiasaan, adat-istiadat, budaya dan keyakinan hal tersebut menyatu dengan diri komunitasnya, hal ini yang membuat kelangsungan kehidupan sosialnya berperilaku (Rismawati, 2014). Lingkungan sosial berkaitan dengan sikap. Sikap kebatinan dan kerohanian dimiliki oleh sebuah masyarakat, sedangkan budaya berkenaan dengan tindakan-tindakan manusia (individu) yang melakukan interaksi dengan lingkungan alamnya guna memenuhi kebutuhan hidupnya.

Bentuk rumah menurut anggapan masyarakat suku Makassar merupakan representasi alam raya ini berbentuk persegi empat. Falsafah atau pandangan hidup ini disebut sulapa appaka yang menjadi ukuran keseimbangan hidup. Oleh karena itu, rumah suku Makassar sebagai mikrokosmos harus berbentuk dasar segi empat. Stratifikasi sosial masyarakat suku Makassar sangat signifikan, hal ini dapat dilihat dari bentuk rumah, luas, dan simbol yang boleh dipakai. Berdasarkan hal tersebut menunjukkan bahwa rumah balla lompoa merupakan kediaman seorang yang memiliki keturunan raja. Bentuk atap yang digunakan pada bangunan balla lompoa merupakan bentuk segitiga yang mempunyai maksu agar air hujan yang jatuh tidak tertampung di atas atap sehingga mencegah terjadinya kebocoran ke dalam rumah.

Bentuk persegi empat yang digunakan pada bagian paladang bangunan balla lompoa merupakan wujud simbolis bahwa rumah ini adalah rumah suku Makassar. Makna yang tersirat adalah bentuk persegi empat ini merupakan bentuk dasar dari bentuk kayu. Seperti yang diketahui rumah balla lompoa ini tersusun dari papan kayu sehingga dengan menggunakan bentuk persegi empat dapat menghemat penggunaan kayu serta proses pembuatan kayu dapat cepat diselesaikan. Papan kayu jati yang digunakan sebagai pembentuk dinding merupakan salah satu ciri khas rumah suku Bugis-Makassar. Rumah merupakan salah satu unsur universal dalam kebudayaan yang memiliki arti simbolik khas yang dapat menunjukkan identitas pemiliknya. Susunan arsitektur suatu rumah merupakan cerminan kebudayaan suatu bangsa. Melihat bangunan rumah maka dapat merekonstruksi tentang bagaimana kehidupan manusia, bekerja, dan mengekspresikan diri. Hampir seluruh perputaran kehidupan manusia terjadi di dalam rumah mulai dari lahir, hidup, dan meninggal (Ansaar, 2015). Kehidupan dilakukan dalam rumah, makan dan tidur anggota keluarga terjadi didalamnya, tamu-tamu diterima dan dijamu. Hasil pertanian sebagai bahan pangan cadangan disimpan di loteng (pammakkang).

Rumah dapat memcerminkan kepribadian orang yang berkediaman di tempat tersebut. Ajaran Islam mengandung nilai sosial (Dahlan, 2017). Hal ini sejalan dengan kepercayaan Islam yang menegaskan kondisi manusia dalam lingkungan sosial dengan berbagai suku dan bangsa membentuk kehidupan sosial, membuat mereka saling membantu dalam kebaikan, kebahagiaan manusia juga terkait dengan hubungan dengan sesamanya. Pembangunan rumah senantiasa mengikuti pola tertentu berdasarkan tradisi yang dapat diterima oleh masyarakat pendukung sehingga rumah tidak dibuat hanya berdasarkan kehendak pribadi yang dibangun dalam rangka memenuhi kebutuhan manusia baik kebutuhan spiritual maupun realistis sehingga pendirian sebuah rumah senantiasa dihubungkan oleh nilai-nilai watak dan kecenderungan, keinginan dan cita-cita kehidupan manusia itu sendiri. Hal demikian merupakan simbol yang membahasakan segala manusia dari pemiliknya, kecenderungan dan kewajaran yang memperteguh jati diri setiap manusia. Berdasarkan hal tersebut rumah merupakan wujud interaksi simbolik dari manusia yang mencerminkan kepribadian yang bermartabat.

Berangkat dari pandangan masyarakat Galesong arsitektur rumah suku Makassar sebagai sebuah hasil kebudayaan di era penjajahan yang didalamnya mengandung kearifan dan pengetahuan lokal. Penggalian, interpretasi, dan integrasi terhadapnya dalam rangka reaktualisasi nilai sesuai semangat ruang dan waktu masa kini yang baik untuk pendidikan khususnya dalam menanamkan nilai ke generasi penerus ataupun masyarakat umum. Keragaman etnis dan budaya mempunyai potensi sangat besar dalam pembentukan dan pengembangan pendidikan melalui integrasi nilai-nilai budaya dalam proses pembelajaran dalam pembentukan kepribadian peserta didik (Syarif, 2017). Oleh karena itu, semua pihak diharapkan untuk melakukan upaya-upaya yang nyata dalam pelestariannya.

\section{Integrasi Arsitektur Rumah Balla Lompoa Suku Makassar sebagai Sumber Materi Geografi Budaya}

Kebudayaan pada masyarakat perlu untuk dikenalkan kepada mahasiswa. Proses pembelajaran dengan sumber materi dari nilai budaya lokal erat kaitannya dengan Pendidikan Geografi. Pengintegrasian nilai budaya pada yang terkandung pada rumah yang diinterpretasikan oleh masyarakat tersebut dapat diwujudkan dalam proses pembelajaran matakuliah Geografi budaya. Menanamkan nilai budaya merupakan bentuk tindakan untuk mewujudkan sikap peduli pada peradaban kebudayaan bangsa yang menjadi identitas nasional yang patut untuk dipahami oleh mahasiswa ataupun masyarakat umum. Tujuan dari matakuliah Geografi budaya diharapkan setelah mengikuti proses perkuliahan mahasiswa memiliki wawasan pengetahuan, pemahaman, serta mampu menganalisis teori, konsep, pendekatan Geografi dalam memahami kebudayaan masyarakat.

Mahasiswa menjadi sasaran membagikan pemahaman budaya lokal yang ada di masyarakat ke mahasiswa diharapakan dengan harapan menerima, mengaplikasikan, dan mentransfer pemahaman itu kepada orang terdekat mereka. Berdasarkan hal tersebut alternatifnya melalui salah satu matakuliah wajib, seperti geografi budaya makna balla lompoa Kabupaten Takalar akan diintegrasikan. Harapan yang lain mengangkat tema makna arsitektur balla lompoa Kabupaten Takalar menjadi refleksi bagi mahasiswa yang tidak berasal dari kultur suku Makassar untuk menggali budaya yang ada pada dirinya ataupun tempatnya. 


\section{SIMPULAN}

Tiga bagian pada rumah balla lompoa masing-masing memiliki kemampuan dan fungsi bukan hanya tempat untuk beristirahat tetapi juga sebagai pelindung bagi penghuninya yang merupakan perwujudan pengaruh iklim dan letak geografis yang melatarbelakangi bentuk dari balla lompoa di Galesong. Arsitektur balla lompoa memiliki simbol-simbol yang mengandung sebuah makna. Makna yang terdapat pada arsitektur balla lompoa merupakan hasil dari interaksi manusia dan alam yang terbentuk di kehidupan masyarakat.

Simbol pada arsitektur balla lompoa diinterpretasikan oleh individu bahwa bangunan tersebut merupakan kediaman seorang karaeng (raja) dengan bentuk orientasi, rinring (dinding), tontongan (jendela), tuka (tangga), sambulayang (bubungan), pakkekbu (pintu), dan paladang (teras) yang menggunakan bentuk persegi empat, hal ini di karenakan masyarakat Galesong berpedoman pada falsafah sulapa appaka dalam membangun rumah yang memiliki makna keseimbangan hidup. Hal ini sesuai dengan pokok bahasan pada matakuliah Geografi Budaya yakni memahami kearifan budaya lokal dan diharapkan dengan mengintegrasikan makna yang terdapat pada arsitektur balla lompoa dalam pembelajaran Geografi Budaya yakni dapat lebih memahami materi serta menanamkan sikap peduli terhadap warisan budaya pada diri mahasiswa agar tidak melupakan kearifan budaya lokal dalam menghadapi perkembangan zaman.

\section{DAFTAR RUJUKAN}

Ansaar. (2015). Arsitektur Tradisional Mamasa. Makassar: Pustaka Refleksi.

Dahlan, M. (2017). Historical Studies on Sarak Values and Their Implementation in Gowa. Mediterranean Journal of Social Sciences, 8(3), 183-188. https://doi.org/10.5901/mjss.2017.v8n3p183

Hendra., Budijanto., \& Ruja, I Nyoman. (2018). Penguatan Kesetiakawanan Sosial Peserta Didik melalui Nilai Budaya Perayaan Maudu Lompoa. Jurnal Pendidikan: Teori, Penelitian, dan Pengembangan, 3(10), 1339-1342.

Johansen, P. (2014). Arsitektur Rumah Betang (Radakng) Kampung Sahapm. Patanjala: Jurnal Penelitian Sejarah dan Budaya, 6(3), 461-474.

Miles, M. B., \& Huberman, A. M. (1984). Qualitative Data Analysis: A Sourcebook of New Methods. California: SAGE Publications Inc.

Rachmah, S. (2018). Rumah Adat Balla Lompoa Kakaraengan Marusu Kassi Kebo di Kabupaten Maros (suatu Kajian Historis). Phinisi Integration Review, 1(1), 37-51.

Rahmawati, T. A., \& Nurcahyo, A. (2018). Makna Simbolik Arsitektur Gereja Santo Cornelius Kelurahan Pangongangan Kecamatan Manguharjo Kota Madiun Jawa Timur. Agastya: Jurnal Sejarah dan Pembelajarannya, 7(2), 103. https://doi.org/10.25273/ajsp.v7i2.1492

Ridwan, M., Fatchan, A., \& Astina, I. K. (2016). Potensi Objek Wisata Toraja Utara Berbasis Kearifan Lokal sebagai Sumber Materi Geografi Pariwisata. Jurnal Pendidikan: Teori, Penelitian, dan Pengembangan, 1(1), 1-10.

Rismawati. (2014). Tradisi Songkabala di Kecamatan Sanrobone Kabupaten Takalar (Suatu Kajian Sosio-Kultural). Rihlah, II (1), 114-131.

Ritzer, G., \& Goodman, D. (2012). Teori Sosiologi Klasik Post Modern. Bantul: Kreasi Wacana.

Suharyono. (2013). Pengantar Filsafat Geografi. Yogyakarta: Ombak.

Syamsunardi. (2017). Nilai-nilai Budaya Siri' Na Pacce Masyarakat Sayye’ Cikoang Kabupaten Takalar Dalam Perspektif Etnografi. Tesis tidak diterbitkan. Universitas Negeri Malang, Malang.

Syarif, E. (2017). Studi Fenomenologi Makna Pasang Ri Kajang Dalam Pengelolaan Hutan Masyarakat Ammatoa Bulukumba Sulawesi Selatan. Universitas Negeri Makassar.

Syarif, E., Hasriyanti., Fatchan, A., Astina, I. K., \& Sumarmi. (2016). Conservation Values of Local Wisdom Traditional Ceremony Rambu Solo Toraja's Tribe South Sulawesi as Efforts the Establishment of Character Education. Efl Journal, $1(1), 17-23$.

Wiryomartono, B. (2013). Soejoedi and Architecture in Modern Indonesia: A Critical Post-Colonial Study. ArchNet-IJAR, 7(1), $177-185$. 